\title{
Reseña del libro: La voz del aprendizaje liberal
}

Miguel Ángel Martínez Romero
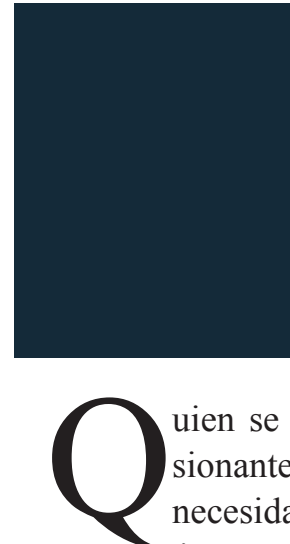

Michael Oakeshott (2009).

La voz del aprendizaje liberal.

España: Katz en coedición con Liberty Fund. correcta interpretación de la persona. La capacidad de enseñar es un rasgo más que distingue al hombre de lo animado y lo inanimado. En el campo educativo instruimos, inspiramos y perfeccionamos personas mediante diversas estrategias, lo cual se hace accesible principalmente a través del diálogo. Hacer comprensible una realidad no es fácil debido al proceso de reflexión y expresión que conlleva. Reflexionar acerca de quiénes somos y lo que hacemos, inclina a la persona a buscar respuestas que la hagan crecer. Aunque el objetivo de la educación es claro, no estamos exentos de pensar una y otra vez en nuestra profesión.

Preocupado por el desarrollo de la filosofía de la educación, Michael Oakeshott expone en las seis conferencias que componen La voz del aprendizaje liberal, una ruta a la cumbre del pensamiento educativo. El lector se encuentra frente a una reflexión filosófica con elementos antropológicos (metafísicos), puesto que no puede haber educación si no hay persona. La tesis que Oakeshott (1975: 23) desarrolla es a partir de su concepto de libertad:

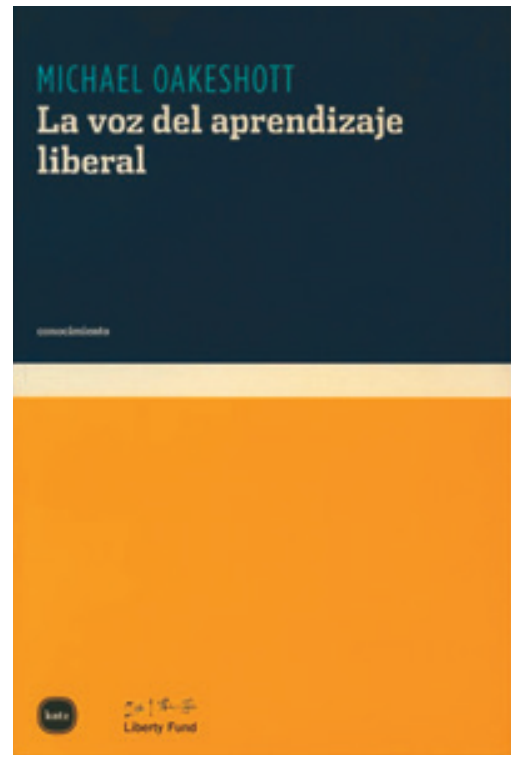

"una presuposición de una existencia consciente en donde hay acciones humanas que presuponen una inteligencia en funcionamiento; donde hay inteligencia en funcionamiento hay libertad".

Uno de los pilares del fracaso educativo es propiciado cuando un profesor se convierte en un mero agente transmisor de conocimientos, y deja en el olvido que hay una persona a la cual educar. La educación no es mera transmisión de conocimientos, es mucho más que eso. El ser humano con su capacidad de elección, hacia lo bueno y lo malo, necesita ser educado; por medio de conocimientos moldea, para bien o para mal, esa presuposición de una existencia consciente conocida como libertad. 
La educación trata de enseñar a ser lo que somos, llevamos impresa en nuestra naturaleza la esencia misma del ser humano; sin embargo, es necesario el aprendizaje, ya que nuestro actuar se afina observando, escuchando, pensando, sintiendo, imaginando, creyendo, comprendiendo, eligiendo, deseando.

En definitiva, los profesores necesitamos repensar nuestra profesión y replantearla como un aprendizaje basado en la libertad. Esto se enfoca en una educación de la imaginación, iniciación en el arte de la conversación en la que aprendemos a reconocer las voces, a adquirir hábitos intelectuales y morales apropiados para una relación conversacional. Así, el alumno gradualmente comprenderá lo que en realidad es. Víktor Frankl (1946: 88), en El hombre en busca de sentido define magistralmente al hombre: "Es el ser que siempre decide lo que es". ${ }^{1}$ La voz del aprendizaje liberal es una exhortación vitalicia (hasta que deje de haber hombres en la tierra) a exigir una mejora en la educación, pues acorde con José Antonio Alcázar (2014: 7), "una persona educada en la libertad es aquella capaz de rechazar las respuestas fáciles y preferidas, porque busca la verdad y conoce el para qué de la libertad". 2

1 Frankl, V. (1992). El hombre en busca de sentido. España: Herder Editorial.

2 Alcázar, J. (2014). La educación de la libertad. España: Identitas Asesores de educación personalizada.

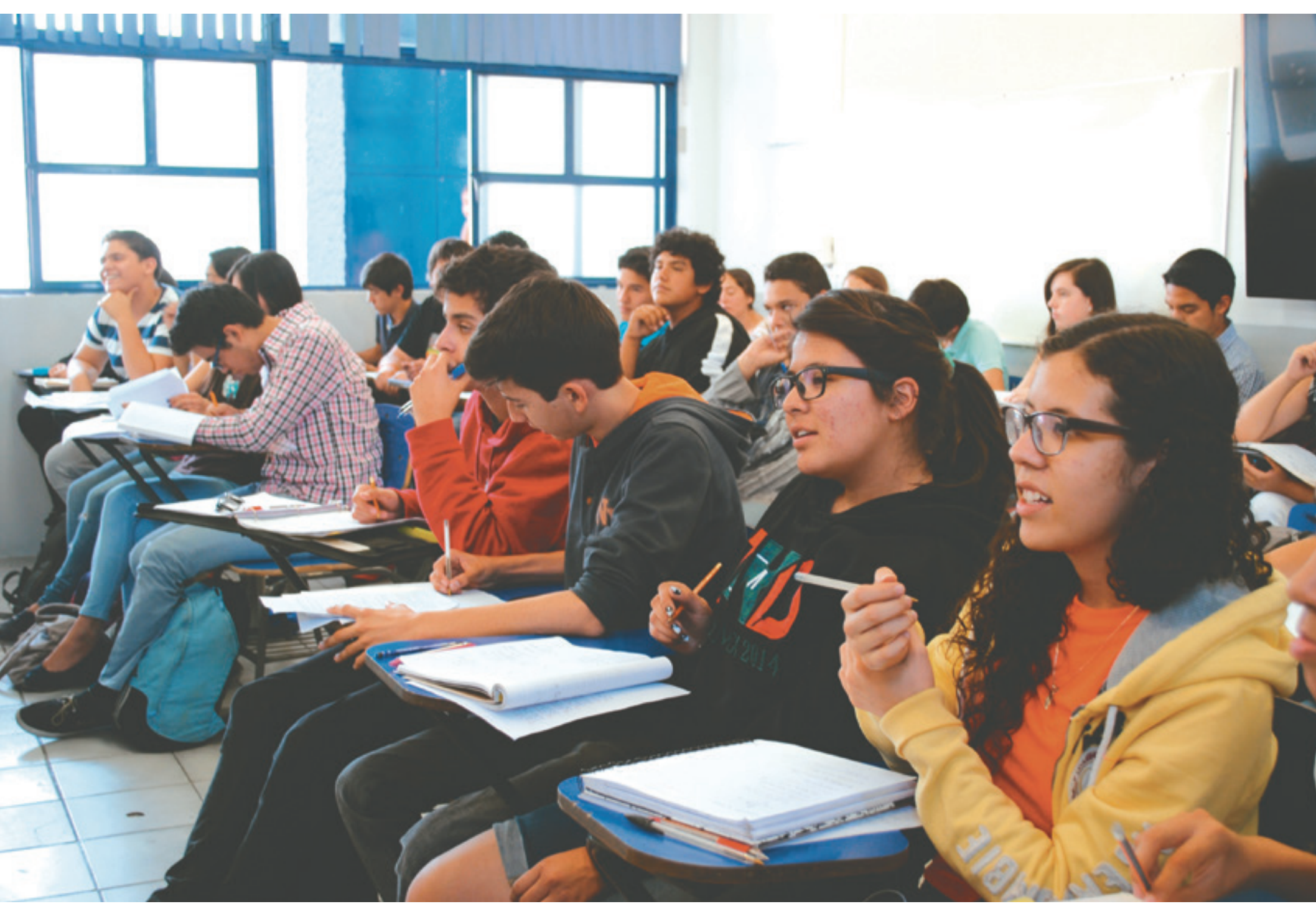

